Egyptian J. of Nutrition Vol. XXXVI No. 1 (2021)

\title{
Effect of dried kiwi and kumquat fruits against azathioprine induced liver toxicity in male albino rats
}

\author{
Mai Hussein Abd-Elfatah', Eman E. Abd-Elhady ${ }^{1}$ \\ and Amira M. El-Moslemany ${ }^{1}$
}

${ }^{1}$ Nutrition and Food Science Department, Faculty of Home Economics, Al-Azhar University, Egypt.

\section{Abstract}

Azathioprine (AZA) is a type of immunosuppressant medicine used in organ transplantation and autoimmune conditions. Therefore, this study aimed to evaluate the role of dried kiwi fruit, kiwi fruit peels and kumquat fruits against liver toxicity induced by azathioprine in male albino rats.Forty- eight male Sprague Dawley rats were divided into two main groups. The group I was served as normal control. Group II was daily received $10 \mathrm{mg} / \mathrm{kg}$ from azathioprine dissolved in saline and gave by gavage for 7 days to induce hepatotoxicity. After that, the second group was divided into equal 7 subgroups. One of these groups kept as (+ve) control group and received basal diet only, at the same time, the experimental fruits were given in the form of powder mixed with the basal diet (kiwi fruit, 5\%\&10\%, kiwi fruit peels 2.5\% \&5\% and kumquat $5 \% \& 10 \%$ ) respectively .At the end of the experiment (4 weeks), the rats were scarified, the serum was analyzed for(AST ),(ALT),(ALP) 


\section{Mai Hussein Abd-Elfatah, Eman E. Abd-Elhady and Amira M. El-Moslemany}

levels, Gamma-glutamyl transferase (GGT), uric acid and creatinine .Also liver tissues were analyzed for superoxide dismutase (SOD), catalase (CAT), malondialdehyde (MDA), as well as histological examination was done Furthermore, feed intake $(F I)$, body weight gain (BWG\%), feed efficiency ratio (FER) and relative weight of liver calculated. Moreover, the proximate composition of fruits were determined. Results elucidated that the tested fruits caused an increase in SOD, CAT and decreased the elevation of AST, ALT, ALP, GGT, uric acid, creatinine, in serum and MDA in liver tissue compared to AZA group.The tested fruits can be served as potent curative agents against the liver toxicity .After testing it on some volunteerswhich, may be due toits anti-oxidant and antiinflammatory activities.

\section{Keywords:}

Azathioprine- immunosuppression -kiwifruit- kiwi peels Kumquat-Antioxidant- liver toxicity.

\section{Introduction}

Azathioprine (AZA) is a type ofimmunosuppressant medicine used in organ transplantation andautoimmune conditions include rheumatoid arthritis andpemphigus disease or chronic bowel disease like crohnan ulcerative colitis disease Manikandaselvi et al., (2015).It is a prodrug, converted into the active metabolite of 6mercaptopurine and 6-thioiosinic acid in the body, weakening the immune response, and reducing the amount of white blood cells that 
Egyptian J. of Nutrition Vol. XXXVI No. 1 (2021)

battle infection. Azathioprine make people more vulnerable to infection when taking medication. The inhibition of purine synthesis, especially affects T-cells and B-cells Hassankhani et al., (2017).

Azathioprine can affect rapidlygrowing cells including bone marrow and gastrointestinalcells, and increase susceptibility to infection andhepatotoxicity (Nørgård et al., 2004); Wu et al., 2006).Furthermore, $A Z A$ is mutagenic, genotoxic, teratogenic andseveral types of tumors are associated with prolongedtreatment with it(Langer et al., 2003);Marcen et al., 2003;Karawya and ElNahas, 2006). Mostly immunosuppressivedrugs induce anemia and disturb the oxidant-antioxidant balance and cause oxidative damage to theliver and other organs. Typically, administration of Azainduces oxidative stress by depleting the activities ofantioxidants and elevating the level of malondialdehydein the liver(Lee and Farrell, 2001). The potential role of dietary antioxidants to reducethe activity of free radical-induced reactions has drawnincreasing attention. Some studies have suggested thatcertain dietary components are associated with lowerAZA risk (Amin and Hamza,2005; Karawya and El-Nahas, 2006). These include vitamins as well as otherphytochemicals, particularly polyphenols.

TheKiwifruit is an incredibly common subtropical fruit amongst consumers. kiwifruit 'Hayward' (Actinidia deliciosa C.F. Liang et A.R. Ferguson) is an essential source of bioactive compounds M. Leontowicz et al.,(2013). Kiwifruit also includes other vitamins, nutrients, and phytochemicals such as carotenoids, 


\section{Mai Hussein Abd-Elfatah, Eman E. Abd-Elhady and Amira M. El-Moslemany}

polyphenolics, and fiber that can be of interest to health beyond basic foods. The benefits primarily fell into the safety focus areas of oxidative stress and mutagenesis defense, cardiovascular health, gut health and immune function Leontowicz et al., (2016). Extracts of kiwi fruit provided protection effect on hepatotoxicity induced both by carbon tetra chloride Kang et al., (2012)and potassium bromate in rats Waffa and Farida, (2012).

The peeling of kiwifruits is rich in procyanidins, which suppresses the development of several inflammatory mediators such as pro-inflammatory cytokines, granzymes B and STAT3 and promotes autophagy on activated human THP-1 monocytes(D'Eliseo et al., 2019).

Kumquat (Citrus japonica var. margarita) is a small, elliptical fruit which is strongly connected to citrus. Taiwan's largest rising field of kumquats is in Ilan city, with more than 90 percent of kumquats produced in Taiwan in the last decade. They are used as common folk medicine to treat respiratory tract inflammation(Lou et al., 2015). Kumquats also have an outstanding food supply andphytochemicals include carotenoids, ascorbic acid, flavonoids and essential oils(Barreca et al., 2011).Also, itreduces destructive impact of free radicals(Aamer and El-Kholy, 2017).Kumquat peels polyphenolics as effective antioxidant agents(Lou et al., 2016).So the current research aimed to evaluate the impact of kiwifruit, kiwi peels and kumquat on the azathioprine-induced hepatotoxicity. 
Egyptian J. of Nutrition Vol. XXXVI No. 1 (2021)

Materials and Methods

\section{Materials:}

Plant samples:- Kiwifruit (Actinide fruits, Family Actinidiaceae) and kumquat fruit (Citrus japonica, Family Rutaceae)were purchased from local markets, Cairo, Egypt.

Chemicals: - Azathioprine B.P uncoated tablets $50 \mathrm{mg}$ was purchased from Sigma Chem. Co., St Louis, Mo. U.S.A. Kits were purchased from Egyptian American Company for Laboratory Service and Supplied by Alkan Company.

Animals:- Forty eight male Sprague Dawley rats, 140-160 g were used. Animals were kept individually in stainless steel cages at room temperature of $25 \pm 2^{\circ} \mathrm{C}$ and a relative humidity about $55 \%$; water and food were given ad libitum.

Diet:- Basal diet was prepared from fine ingredients per 100g.The diet had the following composition:4\%corn oil,3.5\% salt mixture, $1 \%$ vitamin mixture $2.5 \%$ choline , $1 \%$ sucrose, $1.8 \%$ Lcystine , chloride, $14 \%$ casein( $85 \%$ protein), fiber $5 \%$ and corn starch up to $100 \mathrm{~g}$ Reeves et al., (1993).

\section{Methods:}

Preparation of Kiwifruit peel, Kiwi (without peel) and kumquat fruits:

Kiwifruit peel was isolated from fruits, washed with tap water and dried at $60^{\circ} \mathrm{C}$ then crushed to a fine powder. Kiwi (without peel) and kumquat fruits separately were washed with tap water, chopped 


\section{Mai Hussein Abd-Elfatah, Eman E. Abd-Elhady and Amira M. El-Moslemany}

into small pieces and blanched with water vapor, then crushed to a fine powder and added to basal diet as described byHui,(1992).The dried materials were kept in closed dark glass containers in the refrigerator until use.

\section{Determination of proximate composition of thefruits:}

Protein, fat, moisture, ash of kiwifruit, kiwi peels and kumquat were determined according to the method of Horwitz, (2010).

Total carbohydrates were calculated as following:

Carbohydrates $\%=100$ - (moisture $\%+$ protein $\%+$ fat $\%+$ ash $\%+$ Crade fiber \%).

\section{Experimental Design:}

After the adaptation period; the animals were divided into 2 groups. Group I ( $n=6)$ gave basal diet and served as negative(-ve) control group. The second group was daily received $10 \mathrm{mg} / \mathrm{kg}$ from azathioprine dissolved in saline by gavage for 7 days to induce liver toxicity Manikandaselvi et al., (2015).After that, the second group was divided into equal 7 subgroups ( $n=6$ each) as follow: One of these groups kept as positive (+ve) control group and received basal diet only, the others gave the experimental fruits in powder form mixed with the basal diet as follow (kiwifruit 5\%\&10\%, kiwi peels $2.5 \%$ \&5\% and kumquat $5 \% \& 10 \%$ ) respectively. During the experimental period (4 weeks), the quantities of diet which were consumed and leftover diet recorded every day. In addition, rat's 
Egyptian J. of Nutrition Vol. XXXVI No. 1 (2021)

weight was recorded weekly. The body weight gain (BWG\%), feed intake(FI), feed efficiency ratio(FER) and also relative liver weight were calculated according to Chapman et al., (1959). At the end of experiment, the rats were fasted overnight before sacrificed and blood samples were collected from hepatic portal vein for each rat then centrifuged for 10 minutes at 3000 r.p.m. to obtain the serum. Serum was carefully separated and transferred into dry clean eppendorf tubes and kept frozen at $\left(-20^{\circ} \mathrm{C}\right)$ till analysis .Liver was removed, washed with isotonic saline, dried by filter paper and divided into two parts. The first part was kept in formalin saline $10 \%$ for histopathological examination, the second part was kept at $80^{\circ} \mathrm{C}$ for preparation of tissue homogenate for determination of antioxidant parameters. The homogenate was centrifuged at 10.000 r.p.m for $20 \mathrm{~min}$. The supernatant was used for assay malondialdehyde (MDA) as an indicator of lipid peroxidation according to Satoh, (1978), the antioxidant enzymes catalase (CAT) according toAebi, (1984) and superoxide dismutase (SOD) according to Paoletti and Mocali, (1990). In addition, serum concentrations of aspartate aminotransferase (AST) and serum alanine aminotransferase (ALT) performed according to the method described by Reitman and Frankel, (1957).Serum alkaline phosphatase (ALP)determination performed according to the colorimetric method of Roy,(1970). Gamma glutamyle transferase (GGT) enzyme activity determination performed according toKind and King, (1954)also was estimated . Uric acid was determined in the serum according to the method described by Fossati et al., (1980)and serum creatinine as described by Faulkner and King, (1976). 


\section{Mai Hussein Abd-Elfatah, Eman E. Abd-Elhady and Amira M. El-Moslemany}

\section{Histopathological examination:}

Liver was fixed in $10 \%$ neutral buffered formaldehyde solution at $\mathrm{pH}$ 7.5 and cleared in xylol and embedded in paraffin. 4-5 $\mu \mathrm{m}$ thick section prepared and stained with Hematoxylin and Eosin (H\&E) for subsequent histopathological examination according to Carleton, (1979).

\section{Statistical analysis :}

Statistical analysis were done using SPSS version 22. The results were expressed as mean \pm standard deviation (SD) and analyzed statistically using one-way analysis of variance (ANOVA) followed by Duncan test. The differences between means were tested for significance using least significant difference (LSD) test at $p<0.05$ (Snedecor and Cochran, 1979).

\section{Results and discussion}

\section{Proximate composition:}

As shown in table (1), dried kiwifruit, dried kiwifruit peels and dried kumquat fruits analyzed for their chemical composition (moisture, protein, carbohydrates, fat, crude fiber, and ash). It could be noticed that the content in dried kumquat fruits recorded higher percent for carbohydrate than dried kiwi fruit peelsand dried kiwi fruit. On the other hand, dried kiwifruit recorded higher percent from moisture, protein and fat than dried kiwifruit peels and dried kumquat fruit. Meanwhile crude fiber and ash contents were higher 
in dried kiwifruit peels than dried kiwifruit and dried kumquat fruits. Kiwifruit is known as the 'king of fruits' due to its special taste and a wide variety of bioactive compounds that include ascorbic acid, carotenoids, dietary fibers, minerals, and phenolic compounds Lim et al., (2014). Also; kumquat fruit is a rich source of bioactive compounds enriched with more effective antioxidants than those of the citrus species Tan et al., (2014). Henare,(2016)found that kiwifruit are often described as being nutrient dense, andmany species are rich in vitamin C. Selected cultivars arealso goodsourcesof vitaminE, folate, potassium, and dietary fiber. The quantitatively most important dietary fiber constituents in kiwifruit are the

nonstarch polysaccharides intheformofpectic galactans, hemicellulo ses, and cellulose .

The effect of tested fruits on feed intake ,body weight gain\%, , feed efficiency ratio and relative liver weight (\%) :

Data presented in table (2) showed the effect of dried (kiwifruit (5\%\& 10\%), kiwi peels $(2.5 \%$ \& $5 \%$ ), and kumquat fruit $(5 \%$ $\& 10 \%)$ ) on feed intake (FI), body weight gain(BWG) \%, feed efficiency ratio(FER) and relative liver weight( \%) of rats administer azathioprine . Results for $\mathrm{FI}, \mathrm{BWG} \%$ and FER recorded a significant decrease for (+ve) control group when compared to (-ve) control group. Rats received diet supplemented with all tested fruits showed significant increase $(\mathrm{P}<0.05)$ in $\mathrm{FI}, \mathrm{BWG} \%$ and $(\mathrm{FER})$ when compared to (+ve) control group. As respect to the relative liver weight value, it recorded a significant increase in (+ve) control group when compared to (-ve) control group. Rats received diets 


\section{Mai Hussein Abd-Elfatah, Eman E. Abd-Elhady and Amira M. El-Moslemany}

supplemented with dried fruits and kiwi peels showed significant decrease $(P<0.05)$ when compared to $(+v e)$ control group. The administer of AZA causes decrease in $\mathrm{FI}, \mathrm{BWG} \%$ and $\mathrm{FER}$ due to AZA has side effect causes nausea; is the most frequent side effect , diarrhea and fatigue (Mohammadi and Kassim, 2019). Findings of the present study are disagree with Schellekens et al., (1982)who found that administer azathioprine did not cause any changes in the body weight and feed intake when compare with untreated group .Our results agree withTan et al., (2014) who reported that kumquat fruit extract modified BWG to similarity with normal control group. The results obtained byHashish et al., (2017)cleared that diabetic rats fed on whole kumquat recorded high increase in FI, FER and BWG(g) values compared to positive control fed on basal diet. Also, the results agree with Mohamed et al., (2019)whoshowed that ; treated with kumquat crude ethanol extract improved the BWG. Furthermore, El-Dashlouty et al.,(2020)reported that kumquat fruit causes significant increase in BWG , FI and FER compared to (+ve) control. So, the improvement of our result return to the tested fruits. On the other hand El-Dashlouty et al., (2020)showed that rats treated with kumquat fruit cause a significant decrease in relative liver weight compared to (-ve) control group . 
Egyptian J. of Nutrition Vol. XXXVI No. 1 (2021)

\section{Effects of tested fruits on serum biomarkers related to liver functions:}

The biochemical parameters for different experimental groups, summarized in table (3). It was evident that the oral administration with azathioprine caused a significant increase in the levels of AST, $A L T$,ALP and GGT .The treatment with the studied fruits caused decrease in the levels of all the above parameters for all groups. Administer AZA to rats resulted in significant elevation for ALT, AST, ALP and GGT in the serum of the rats . El-Beshbishy et al., (2011)found thatthe AZA-induced hepatotoxicity observed 24 hours post treatment is documented by significant increments in the activities of both serum ALT and AST and confirmed by histological changes in liver of male albino rats. These changes were corrected to normalcy upon oral administration of either kiwifruit or kumquat to AZA-intoxicated rats. The ALT, AST and ALP estimations are used in the evaluation of hepatic disorders. An increase in these enzyme levels reflects active liver damage. Inflammatory hepatocellular disorders result in high transaminase levels (Hultcrantz et al., 1986). The increase of ALT, AST and ALP levels indicated liver dysfunction and might be mainly due to leakage of these enzymes from liver cytosol into blood (Eliza et al., 2009). Also ,Gaur and Bhatia, (2009)reported thatthis elevation is might be due to the damage of cellular membranes of hepatocytes, which in turn leads to an increase in the permeability of cell membranes, facilitates the passage of cytoplasmic enzymes outside the cells leading to the elevation in aminotransferase activities in the serum. Jack et al., (2016)reported that the most common pattern of hepatotoxicity by AZA seen was gamma-glutamyl transpeptidase 


\section{Mai Hussein Abd-Elfatah, Eman E. Abd-Elhady and Amira M. El-Moslemany}

(GGT) enzyme elevation in $67.8 \%$ of patients. Elbadrawy and Elkewawy, (2019)revealed significant decrease in serum levels of GGT of the treated groups by kiwifruit in comparing with the positive control.

Hemdan and Abdulmaguid, (2020) showed that kiwifruit as nutritional sources helped to bring back serum levels of AST and ALT enzymes .Also, Abdallah et al., (2019)reported thatirradiated rats treated with kumquat fruit extract showed a significant decrease the level of liver enzymes (ALT, AST and GGT) of irradiated rats, which is in agreement with the findings of (Elabd,2015). Hashish et al., (2017)found that the lowest serum AST, ALT \& ALP levels recorded for diabetic rats fed on whole kumquat $5 \%$ with significant difference $(p<0.001)$ compared to positive control fed on basal diet. Also, Abdallah et al., (2019)showed that the strong efficiency role of kumquat fruit extract as an antioxidant against hepatotoxicity through enhancement of liver function ( ALT, AST and GGT).

Effect of dried kiwifruit, kiwifruit peels and kumquat on SOD ,CAT and MDA levels in the liver homogenate for rats administer azathioprine:

The biochemical parameters of liver tissue of the studied groups are summarized in table (4). Oral administration with azathioprine caused an elevation in the MDA and reduction for CAT and SOD in the liver tissue. On the other side, feeding on dried kiwifruit, kiwi peels and kumquat with two doses suppressed the elevation of MDA and increase CAT and SOD in liver tissue ; thus 
Egyptian J. of Nutrition Vol. XXXVI No. 1 (2021)

attenuated the oxidative stress. Antioxidant enzymes such as SOD and CAT play an important role in the elimination of reactive oxygen species and protects against oxidative stress. In accordance with the previous findings, the significant decrease in SOD and CAT activity was due to exhaustion of the enzymes as a result of oxidative stress caused by AZA (Amin and Hamza,2005). Nevertheless, kiwifruit, kiwi peel and kumquat treatment bolstered the antioxidant defense system as shown by increase tissue levels of SOD and CAT which could be attributed to the presence of polyphenols and other antioxidants like vitamin C. Lipid peroxidation is a free radical-inducible cycle in which the membrane polyunsaturated fatty acids are transformed oxidatively into a range of products like MDA (Matalon et al., 2004). In the present study, the elevation of MDA was observed in AZA-intoxicated rats, which is suggestive of lipid peroxidation activation resulting in excessive free radical production.

It could be worthy of noting that these remarks are compatible with the results recorded by Amin and Hamza, ( 2005). However, upon pretreatment with kiwifruit, kiwi peel and kumquat the MDA level was significantly decreased. The supposition was that the phytoconstituents present in kiwifruit, kiwi peel and kumquat functioned as antioxidants/anti-lipid peroxidants, by protecting membrane lipids from propagating oxidative damage through termination of peroxyl radical mediated reactions. Azathioprine administration causes decrease in SOD, CAT, and increase MDA rates (Shanmugarajan et al., 2008). Matsuo et al., (2014) showed that the production of SOD decreased dramatically 


\section{Mai Hussein Abd-Elfatah, Eman E. Abd-Elhady and Amira M. El-Moslemany}

as the result of administration with AZA.Mohamed et al., (2019) reported that administration of kumquat fruits suppressed MDA elevation and increased CAT level .Feeding on kumquat fruit suppressed MDA exhibited the highest levels of TNF- $\alpha$. The improvement of SOD, CAT and MDA return to the treatment with the tested fruits may be due to their content from ascorbic acid (Boland, 2013).

Effect of kiwifruit, kiwifruit peels and kumquat on uric acid and creatinine for rats administerazathioprine:

Table (5) revealed that rats which, administer AZA and had no treatment $(+v)$ group showed increase in uric acid and creatinine levels. The treated groups with dried fruits suppressed the elevation of the levels for all of the above parameters. In our study elevation of uric acid and creatinine were the most established kidney changes due to the administer AZA but the treatment with fruits improve the kidney changes. This improvement may be due to the content of these fruits from antioxidant compounds. Hemdan and Abdulmaguid, (2020) showed that kiwifruit as nutritional sources helped to bring back serum levels of creatinine activities. Hashish et al., (2017)revealed that rats fed on whole kumquat $2.5 \%$ \& $5 \%$, decrease uric acid \& creatinine $(\mathrm{mg} / \mathrm{dl})$ compared to positive control fed on basal diet. On the other hand the results of this work are partially agree with El-Dashlouty et al., (2020)who showed that rats treated with kumquat showed significant decrease in serum creatinine $(\mathrm{mg} / \mathrm{dl})$, urea $(\mathrm{mg} / \mathrm{dl})$ \&uric acid $(\mathrm{mg} / \mathrm{dl})$ into consideration that the highest decreased limit of serum creatinine $(\mathrm{mg} / \mathrm{dl}) \&$ urea 
Egyptian J. of Nutrition Vol. XXXVI No. 1 (2021)

(mg/dl) obtained for G3 (whole kumquat seedless 7.5\%). The effect of vitamin $\mathrm{C}$ as an antioxidant are well known. It crushes out free radicals and other nitrogen and reactive oxygen forms. It also has the capacity to regenerate other antioxidants (Carr and Frei, 1999. Carr et al., 2013) and thus prevents biomolecules such as DNA and lipids from oxidative harm(Mandl et al., 2009 ;DGE, 2015).Because kumquat contains vitamin $\mathrm{C}$ and phenolic compound it improves liver enzymes (AST, ALT , ALP) and kidney function (uric acid ,creatinine).

\section{Histopathological examination of liver tissue:}

Microscopically, liver of rats of negative control group (group1) revealed the normal histological structure of hepatic lobule (photo 1). On the other hand, liver of rats for positive control group (group2) showed large and small hepatocytes nuclei, karyolysis of nuclei $(\mathrm{KL})$, haemerage in sinusoids $(\mathrm{S})$, increasing in Kupffer cells (K) (photo 2 ). However, some examined sections from group treated with dried kiwifruit 5\%(group3) showed normal central vein (cv), hepatic cells $(H)$ radiated from central vein and sinusoids $(S)$, inflitration of lymphocytes (L) and vacuolation of cytoplasm ( $\mathrm{O}$ )(photo 3). Moreover, some sections from (group 4) treated with dried kiwi fruits $10 \%$ showed no histopathological changes (photo 4), where, showing approximately normal central vein , hepatic cells and sinusoids (S). Liver of rats treated with dried kiwi peels $2.5 \%$ from (group 5 )revealed normal central vein , normal hepatocytes are noticed (phots5). Also, examined sections from rats treated with dried kiwi peels $5 \%$ (group 6) showed normal central vein , with hepatocytes proliferation (photos 6 ).In addition , examined sections 


\section{Mai Hussein Abd-Elfatah, Eman E. Abd-Elhady and Amira M. El-Moslemany}

from rats treated with dried kumquat $5 \%$ (group 7) showed normal central vein , with normal of hepatocytes (photo7 ). Moreover, some sections from (group8) treated with dried kumquat fruit 10\% showed normal central vein , with normal appearance of hepatocytes ( photo 8). Khudhair, (2018) showed that the histopathological examination of liver for treated animals with azathioprine showed dilation of portal vein with congestion, mononuclear cell aggregation (MNC) and dilation of sinusoids and the harmful effect of azathioprine on the infected tissues may be due to azathioprine toxicity. Also, $\boldsymbol{M}$. Leontowicz et al.,(2016) showed that changes in the liver were smaller in the groups of rats receiving kiwifruit.

\section{Conclusion}

Treated with kiwifruit, kiwi peels and kumquat fruit reverse the negative effects of AZA in rats, including the reduction in CAT and SOD, the elevation in MDA in the liver tissue. Also, decreased the elevation of liver enzymes (AST,ALT,ALP,GGT) and (uric acid, creatinine|). The tested fruits can be served as potent curative agents against the liver toxicity which, may be due toits anti-oxidant and anti-inflammatory activities. 
Egyptian J. of Nutrition Vol. XXXVI No. 1 (2021)

Table (1): Proximate composition of dried( kiwifruit, kiwifruit peels and kumquat fruits \%) :

\begin{tabular}{l|l|l|l|l|l|l}
\hline Sample & Moisture\% & Protein\% & Carbohydrate\% & Fat\% & $\begin{array}{c}\text { Crude } \\
\text { Fiber\% }\end{array}$ & Ash\% \\
\hline Dried kiwifruit & 12.54 & 5.18 & 69.29 & 2.63 & 6.59 & 3.77 \\
\hline Dried kiwi peels & 10.88 & 4.64 & 63.47 & 1.22 & 15.33 & 4.46 \\
\hline Dried kumquat fruit & 10.88 & 4.98 & 77.61 & 1.15 & 3.13 & 2.25 \\
\hline
\end{tabular}

Table (2): Effect of dried( kiwi fruit ,kiwi fruit peels and kumquat fruits) on feed intake , body weight gain\%, feed efficiency ratio and relative liver weight $\%$ in rats administer azathioprine :

\begin{tabular}{c|c|c|c|c}
\hline Proups & FI (g/day) & BWG\% & FER & Liver \\
\hline (-ve ) Control & $21.96 \pm 1.43^{\mathrm{a}}$ & $42.06 \pm 5.82^{\mathrm{a}}$ & $0.153 \pm 0.004^{\mathrm{a}}$ & $2.13 \pm 0.429^{\mathrm{d}}$ \\
\hline (+ve ) Control & $11.66 \pm 0.80^{\mathrm{f}}$ & $07.94 \pm 2.26^{\mathrm{d}}$ & $0.050 \pm 0.007^{\mathrm{e}}$ & $3.66 \pm 0.299^{\mathrm{a}}$ \\
\hline Kiw $(5 \%)$ & $16.76 \pm 0.85^{\mathrm{c}}$ & $27.88 \pm 3.51^{\mathrm{b}}$ & $0.095 \pm 0.014^{\mathrm{cd}}$ & $2.88 \pm 0.111^{\mathrm{b}}$ \\
\hline Kiw $(10 \%)$ & $14.63 \pm 0.45^{\mathrm{de}}$ & $18.65 \pm 3.07^{\mathrm{c}}$ & $0.123 \pm 0.008^{\mathrm{abc}}$ & $2.62 \pm 0.152^{\mathrm{bcd}}$ \\
\hline Kiw.Peel $(2.5 \%)$ & $13.43 \pm 0.05^{\mathrm{e}}$ & $34.59 \pm 4.23^{\mathrm{b}}$ & $0.113 \pm 0.014^{\mathrm{bcd}}$ & $2.67 \pm 0.557^{\mathrm{bc}}$ \\
\hline Kiw. Peel $(5 \%)$ & $13.83 \pm 0.45^{\mathrm{de}}$ & $15.39 \pm 2.28^{\mathrm{c}}$ & $0.087 \pm 0.019^{\mathrm{d}}$ & $2.26 \pm 0.133^{\mathrm{cd}}$ \\
\hline Kum $(5 \%)$ & $19.43 \pm 0.92^{\mathrm{b}}$ & $19.63 \pm 5.17^{\mathrm{c}}$ & $0.128 \pm 0.041^{\mathrm{ab}}$ & $2.66 \pm 0.136^{\mathrm{bc}}$ \\
\hline Kum(10\%) & $14.83 \pm 0.49^{\mathrm{d}}$ & $17.03 \pm 3.45^{\mathrm{c}}$ & $0.113 \pm 0.011^{\mathrm{bcd}}$ & $2.27 \pm 0.225^{\mathrm{cd}}$ \\
\hline LSD & 1.36 & 6.77 & 0.031 & 0.51 \\
\hline
\end{tabular}

Values are expressed as mean \pm S.D.

Significance is expressed at $p<0.05$ using one way ANOVA test and LSD test.

Values which have different letters in each column differ significantly, while those with similar letters completely or partially is not significant. 


\section{Mai Hussein Abd-Elfatah, Eman E. Abd-Elhady and Amira M. El-Moslemany}

Table (3): Effect of dried kiwifruit, kiwifruit peels and kumquat on serum AST, ALT , ALP and GGT for rats administer azathioprine

\begin{tabular}{|c|c|c|c|c|}
\hline Groups & AST(U/L) & $\mathrm{ALT}(\mathrm{U} / \mathrm{L})$ & $\operatorname{ALP}(\mathrm{U} / \mathrm{L})$ & $\mathrm{GGT}(\mathrm{U} / \mathrm{L})$ \\
\hline (-ve ) Control & $\begin{array}{c}112.31 \pm \\
4.11^{\mathrm{e}}\end{array}$ & $\begin{array}{l}39.63 \\
\pm 2.49^{f}\end{array}$ & $\begin{array}{c}87.08 \pm \\
11.6 \cdot e\end{array}$ & $\begin{array}{c}3.15 \pm \\
0.26^{\mathrm{g}}\end{array}$ \\
\hline (+ve ) Control & $\begin{array}{c}261.86 \pm \\
11.25^{\mathrm{a}}\end{array}$ & $\begin{array}{c}165.10 \pm 18 . \\
3 \cdot a\end{array}$ & $\begin{array}{c}161.70 \pm \\
7.05^{a}\end{array}$ & $\begin{array}{c}8.02 \pm \\
0.14^{\mathrm{a}}\end{array}$ \\
\hline $\operatorname{Kiw}(5 \%)$ & $\begin{array}{c}195 \cdots . \pm \\
0 ., \ldots b\end{array}$ & $\begin{array}{c}127.50 \pm \\
10.7 \cdot b\end{array}$ & $\begin{array}{c}130.02 \pm \\
1.61^{c}\end{array}$ & $\begin{array}{c}6.43 \pm \\
0.11^{\mathrm{c}}\end{array}$ \\
\hline $\operatorname{Kiw}(10 \%)$ & $\begin{array}{c}197.6 \cdot \pm \\
5.8 \cdot b\end{array}$ & $\begin{array}{c}101.73 \pm \\
3.57^{c}\end{array}$ & $\begin{array}{c}127.73 \pm \\
2.43^{c}\end{array}$ & $\begin{array}{l}5.49 \pm \\
0.15^{d}\end{array}$ \\
\hline Kiw . Peel (2.5\%) & $\begin{array}{c}170.25 \pm \\
13.9 \cdot c\end{array}$ & $\begin{array}{c}82.12 \pm \\
2.99^{d}\end{array}$ & $\begin{array}{c}140.98 \pm \\
4.55^{\mathrm{b}}\end{array}$ & $\begin{array}{l}4.92 \pm \\
0.08^{e}\end{array}$ \\
\hline Kiw. Peel (5\%) & $\begin{array}{c}168.4 \cdot \pm \\
2.1 \cdot c\end{array}$ & $\begin{array}{c}077.67 \pm \\
3.5 \cdot d\end{array}$ & $\begin{array}{c}140.93 \pm \\
0.75^{\mathrm{b}}\end{array}$ & $\begin{array}{l}4.85 \pm \\
0.31^{e}\end{array}$ \\
\hline Kum (5\%) & $\begin{array}{c}136.75 \pm \\
11.45^{d}\end{array}$ & $\begin{array}{c}135.70 \pm \\
10.5 \cdot b\end{array}$ & $\begin{array}{c}104.35 \pm \\
6.46^{d}\end{array}$ & $\begin{array}{c}3.83 \pm \\
0.21^{f}\end{array}$ \\
\hline Kum (10\%) & $\begin{array}{c}197.68 \pm 3.42 \\
\text { b }\end{array}$ & $\begin{array}{l}061.82 \\
\pm 6.58^{\mathrm{e}}\end{array}$ & $\begin{array}{c}103.85 \pm \\
2.55^{d}\end{array}$ & $\begin{array}{c}6.96 \\
\pm 0.22^{\mathrm{b}}\end{array}$ \\
\hline LSD & 14.80 & 15.52 & 09.38 & 0.34 \\
\hline
\end{tabular}

Values are expressed as mean \pm S.D.

Significance is expressed at $p<0.05$ using one way ANOVA test and LSD test.

Values which have different letters in each column differ significantly, while those with similar letters completely or partially is not significant. 
Egyptian J. of Nutrition Vol. XXXVI No. 1 (2021)

Table (4): Effect of dried kiwifruit, kiwifruit peels and kumquat on SOD ,CAT and MDA levels in the liver homogenate for rats administer azathioprine:

\begin{tabular}{|c|c|c|c|}
\hline Groups & $\mathrm{SOD}(\mathrm{U} / \mathrm{mg})$ & CAT (ng/mg) & MDA $(\mathrm{nmol} / \mathrm{mg})$ \\
\hline (-ve ) Control & $\begin{array}{l}0.372 \pm \\
0.018^{a}\end{array}$ & $\begin{array}{c}0.400 \pm \\
0.016^{a}\end{array}$ & $\begin{array}{l}0.112 \pm \\
0.004 \mathrm{~g}\end{array}$ \\
\hline (+ve ) Control & $\begin{array}{c}0.104 \pm \\
0.003^{h}\end{array}$ & $\begin{array}{c}0.108 \pm \\
0.002^{\mathrm{g}}\end{array}$ & $\begin{array}{c}0.405 \pm \\
0.011^{\mathrm{a}}\end{array}$ \\
\hline $\operatorname{Kiw}(5 \%)$ & $\begin{array}{c}0.161 \pm \\
0.003^{f}\end{array}$ & $\begin{array}{c}0.168 \pm \\
0.002^{\mathrm{e}}\end{array}$ & $\begin{array}{c}0.273 \pm \\
0.005^{c}\end{array}$ \\
\hline $\operatorname{Kiw}(10 \%)$ & $\begin{array}{l}0.193 \pm \\
0.004^{\mathrm{e}}\end{array}$ & $\begin{array}{c}0.198 \pm \\
0.002^{d}\end{array}$ & $\begin{array}{l}0.214 \pm \\
0.007^{d}\end{array}$ \\
\hline Kiw.Peel(2.5\%) & $\begin{array}{c}0.238 \pm \\
0.012^{c}\end{array}$ & $\begin{array}{l}0.253 \pm \\
0.012^{\mathrm{c}}\end{array}$ & $\begin{array}{l}0.171 \pm \\
0.007^{\mathrm{e}}\end{array}$ \\
\hline Kiw. Peel (5\%) & $\begin{array}{l}0.219 \pm \\
0.006^{d}\end{array}$ & $\begin{array}{l}0.201 \pm \\
0.007^{d}\end{array}$ & $\begin{array}{l}0.201 \pm \\
0.012^{d} \\
\end{array}$ \\
\hline Kum (5\%) & $\begin{array}{l}0.267 \pm \\
0.003^{b}\end{array}$ & $\begin{array}{l}0.281 \pm \\
0.008^{b}\end{array}$ & $\begin{array}{l}0.152 \pm \\
0.008^{f}\end{array}$ \\
\hline $\operatorname{Kum}(10 \%)$ & $\begin{array}{l}0.131 \pm \\
0.006^{g}\end{array}$ & $\begin{array}{c}0.140 \pm \\
0.009^{f}\end{array}$ & $\begin{array}{c}0.307 \pm \\
0.006^{b}\end{array}$ \\
\hline LSD & 0.015 & 0.015 & 0.013 \\
\hline
\end{tabular}

Values are expressed as mean \pm S.D.

Significance is expressed at $p<0.05$ using one way ANOVA test and LSD test.

Values which have different letters in each column differ significantly, while those with similar letters completely or partially is not significant. 


\section{Mai Hussein Abd-Elfatah, Eman E. Abd-Elhady and Amira M. El-Moslemany}

Table(5): Effect of dried kiwifruit, kiwifruit peels and kumquat on uric acid and creatinine for rats administer azathioprine

\begin{tabular}{|c|c|c|}
\hline $\begin{array}{ll}\text { Groups } & \text { Parameters }\end{array}$ & Uric acid $(\mathrm{mg} / \mathrm{dl})$ & Creatinine $(\mathrm{mg} / \mathrm{dl})$ \\
\hline (-ve ) Control & $1.97 \pm 0.02^{\mathrm{e}}$ & $0.49 \pm 0.04^{\dagger}$ \\
\hline (+ve ) Control & $3.93 \pm 0.37^{a}$ & $1.18 \pm 0.05^{a}$ \\
\hline $\operatorname{Kiw}(5 \%)$ & $3.12 \pm 0.045^{\mathrm{bc}}$ & $0.94 \pm 0.005^{b}$ \\
\hline $\operatorname{Kiw}(10 \%)$ & $3.22 \pm 0.03^{b c}$ & $0.83 \pm 0.02^{c}$ \\
\hline Kiw.Peel (2.5\%) & $2.75 \pm 0.15^{d}$ & $0.73 \pm 0.02^{d}$ \\
\hline Kiw. Peel (5\%) & $2.97 \pm 0.015^{\mathrm{cd}}$ & $0.70 \pm 0.02^{d}$ \\
\hline Kum (5\%) & $3.37 \pm 0.02^{b}$ & $0.60 \pm 0.025^{\mathrm{e}}$ \\
\hline Kum(10\%) & $2.87 \pm 0.03^{d}$ & $0.95 \pm 0.03^{b}$ \\
\hline LSD & 0.25 & 0.05 \\
\hline
\end{tabular}

Values are expressed as mean \pm S.D.

Significance is expressed at $p<0.05$ using one way ANOVA test and LSD test.

Values which have different letters in each column differ significantly, while those with similar letters completely or partially is not significant. 
Egyptian J. of Nutrition Vol. XXXVI No. 1 (2021)

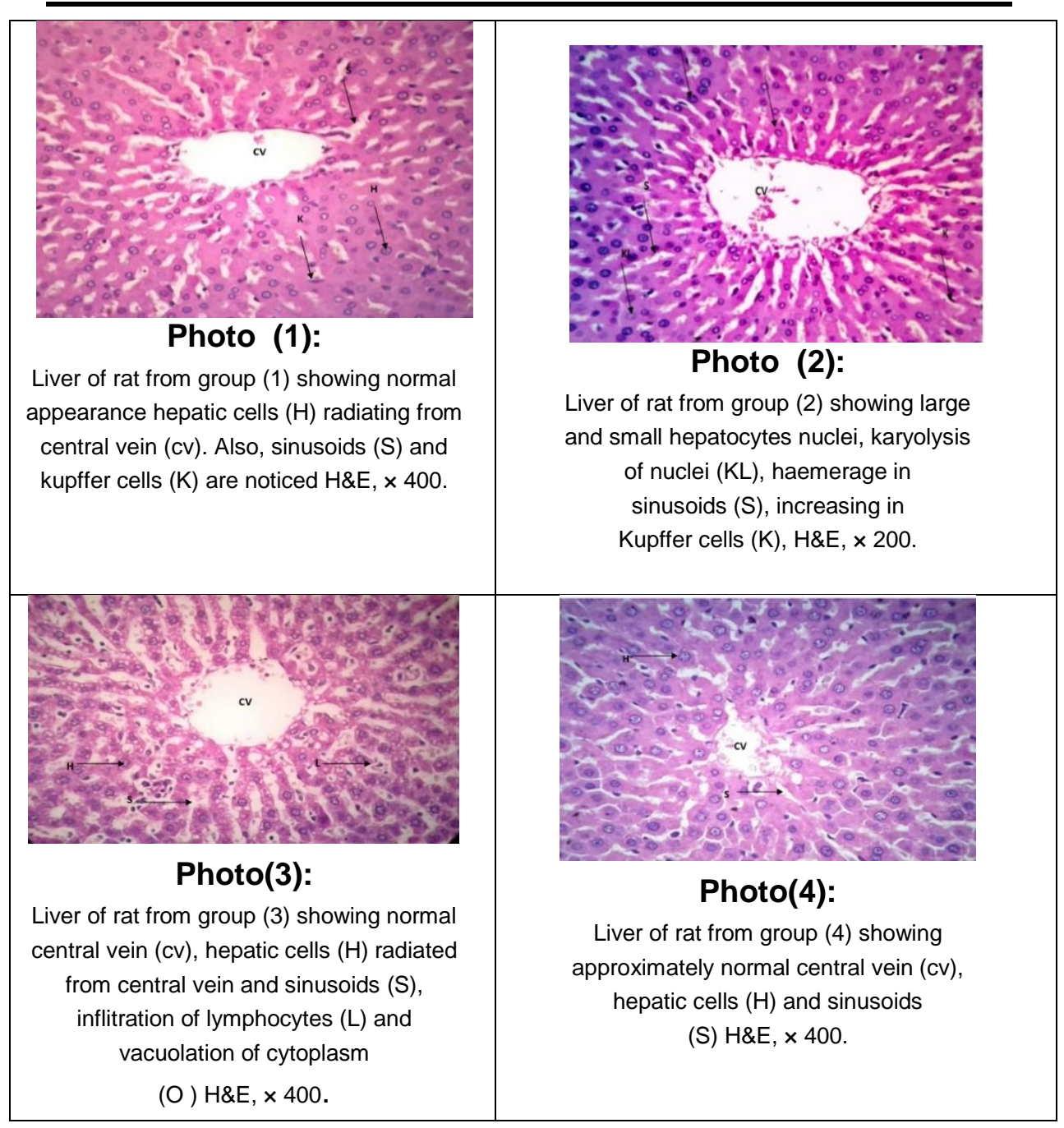




\section{Mai Hussein Abd-Elfatah, Eman E. Abd-Elhady and Amira M. El-Moslemany}

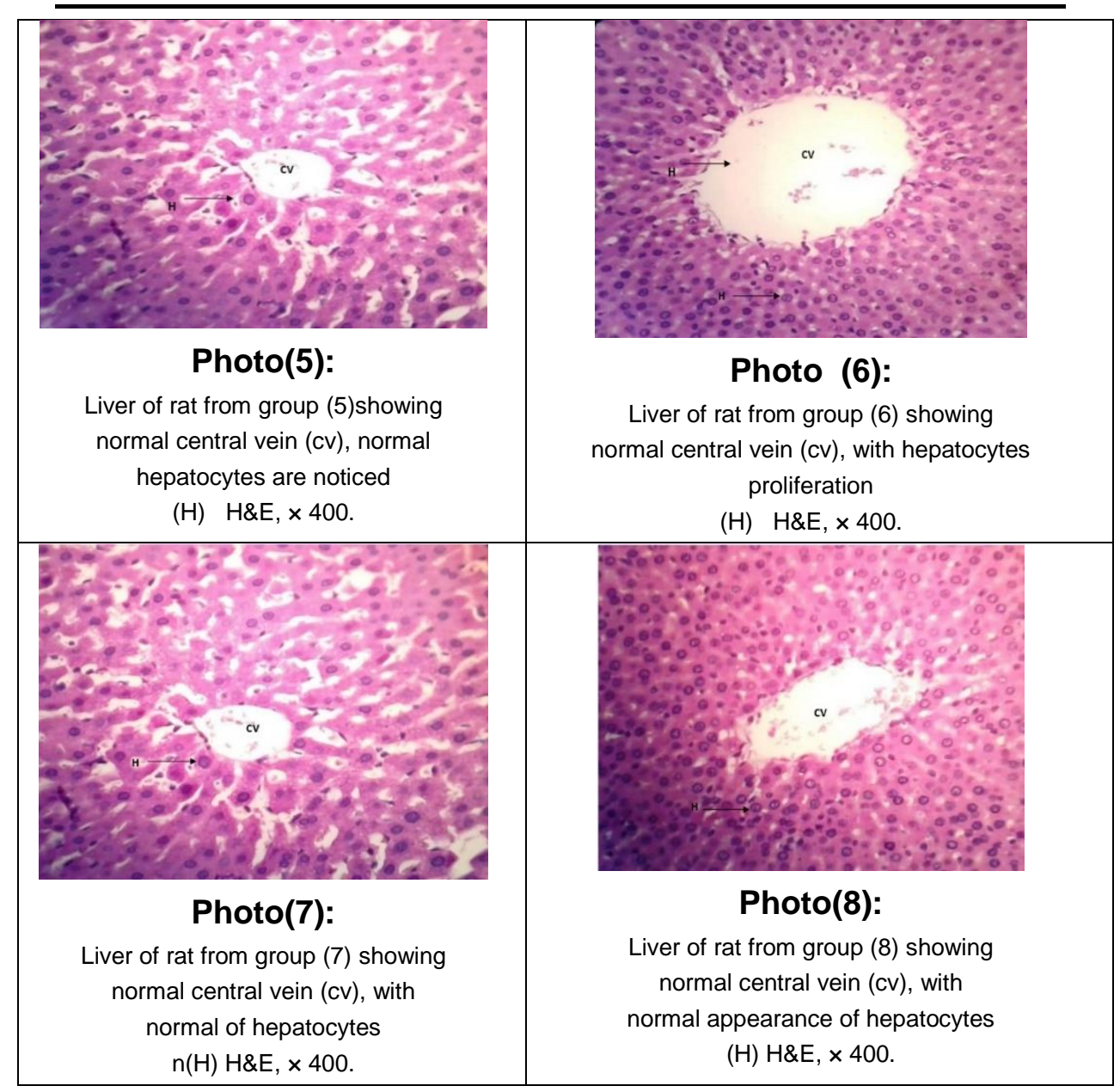


Egyptian J. of Nutrition Vol. XXXVI No. 1 (2021)

\section{References}

(DGE), G. N. S. (2015).

New reference values for vitamin $C$ intake.

Aamer, R., and El-Kholy, W. (2017) .

Production of functional beverages from whey and permeate containing kumquat fruit. Alexandria Journal of Food Science and Technology, 14(1), 41-56.

Abdallah, I. Z. A., Ahmed, M. M., Montaser, S. A., and Hafez, S. S. (2019).

Efficiency of Kumquat Fruit (Fortunella margarita) Extract against Hepatotoxicity and Infertility Induced by Gamma Irradiation in Male Albino Rats. Egyptian Journal of Radiation Sciences and Applications, 32(2), 187-199.

Aebi, H. (1984).

[13] Catalase in vitro. In Methods in enzymology (Vol. 105, pp. 121-126). Elsevier.

Amin, A., and Hamza, A. A. (2005).

Hepatoprotective effects of Hibiscus, Rosmarinus and Salvia on azathioprine-induced toxicity in rats. Life Sciences, 77(3), 266-278. 


\section{Mai Hussein Abd-Elfatah, Eman E. Abd-Elhady and Amira M. El-Moslemany}

Barreca, D., Bellocco, E., Caristi, C., Leuzzi, U., and Gattuso, G. (2011).

Kumquat ( Fortunella japonica Swingle ) juice: Flavonoid distribution and antioxidant properties. FRIN, 44(7), 21902197. 1

Boland, M. (2013).

Kiwifruit proteins and enzymes: actinidin and other significant proteins. In Advances in food and nutrition research (Vol. 68, pp. 59-80). Elsevier.

Carleton, H. (1979).

Bone and decalcification: Carletons histological techniques. Messrs Churchill Livingstone, London, 199-207.

Carr, A. C., Bozonet, S. M., Pullar, J. M., Simcock, J. W., and Vissers, M. C. M. (2013).

Human skeletal muscle ascorbate is highly responsive to changes in vitamin $\mathrm{C}$ intake and plasma concentrations. The American Journal of Clinical Nutrition, 97(4), 800-807.

Carr, A., and Frei, B. (1999).

Does vitamin $C$ act as a pro-oxidant under physiological conditions? The FASEB Journal, 13(9), 1007-1024. 
Egyptian J. of Nutrition Vol. XXXVI No. 1 (2021)

Chapman, D. G., Castillo, R., and Campbell, J. A. (1959).

Chapman. Canadian Journal of Biochemistry and Physiology, 37(5), 679-686.

D’Eliseo, D., Pannucci, E., Bernini, R., Campo, M., Romani, A., Santi, L., and Velotti, F. (2019).

In vitro studies on anti-inflammatory activities of kiwifruit peel extract in human THP-1 monocytes. Journal of Ethnopharmacology, 233, 41-46.

El-Beshbishy, H. A., Tork, O. M., El-Bab, M. F., and Autifi, M. A. (2011).

Antioxidant and antiapoptotic effects of green tea polyphenols against azathioprine-induced liver injury in rats. Pathophysiology, 18(2), 125-135.

El-Dashlouty, M. S., El-Sherif, F. E.-Z. A., and Diab, L. A. (2020). Pineapple And Kumquat Powders Used To Combat The Oxidation Stress Induced By Potassium Bromate In Male Albino Rats. Egyptian Journal for Specialized Studies-Vol, $8(25)$.

Elabd, E. (2015).

Phytochemical and Biological Studies on Fortunella margarita (Lour.) Swingle (Kumquat)(Rutaceae) Growing in Egypt. M. Sc. Thesis. 


\section{Mai Hussein Abd-Elfatah, Eman E. Abd-Elhady and Amira M. El-Moslemany}

Elbadrawy, E., and Elkewawy, H. (2019).

Alleviation of Tramadol-Induced Liver Toxicity in Experimental Rats by Using Kiwifruit, Turmeric Extract or Their Combination. Journal of Food and Dairy Sciences, 10(10), 381-387.

Eliza, J., Daisy, P., Ignacimuthu, S., and Duraipandiyan, V. (2009).

Antidiabetic and antilipidemic effect of eremanthin from Costus speciosus (Koen.) Sm., in STZ-induced diabetic rats. Chemico-Biological Interactions, 182(1), 67-72.

Faulkner, W. R., and King, J. W. (1976).

Renal function. In Fundamentals of clinical chemistry (pp. 994-998). Saunders Philadelphia, PA.

Fossati, P., Prencipe, L., and Berti, G. (1980).

Use of 3, 5-dichloro-2-hydroxybenzenesulfonicacid/4aminophenazone chromogenic system in direct enzymic assay of uric acid in serum and urine. Clinical Chemistry, 26(2), 227-231.

Gaur, A., and Bhatia, A. L. (2009).

Modulation of phosphatase levels in mice liver by genistein treatment against radiation exposure. Pharmacognosy Research, 1(2), 72. 
Egyptian J. of Nutrition Vol. XXXVI No. 1 (2021)

Hashish, Hashish, A. S., Shaheen, K. A., and Abd EI-Aazez, S. A. (2017).

Study Kumquat Effect on Rats Infected with Diabetes. Thesis (M.S)- Menoufia Univ. Faculty of Home Economic, Dept. Nutrition and Food Sci.

Hassankhani, M., Aldavood, S. J., khosravi, alireza, sasani, farhang, masoudifard, M., Ansari, F., and Taheri, M. T. (2017).

The effects of prolonged azathioprine administration on blood cells, lymphocytes and immunoglobulins of Iranian mixed-breed dogs. Iranian Journal of Veterinary Medicine, 11(4), 361-377.

Hemdan, D. I., and Abdulmaguid, N. Y. M. (2020).

Study the effect of star anise extract and the pulp of kiwifruit on mice infected with cancer. CURRENT SCIENCE, 118(1), 87.

Henare, S. J. (2016).

Chapter 15 - The Nutritional Composition of Kiwifruit (Actinidia spp.) (M. S. J. Simmonds and V. R. B. T.-N. C. of F. C. Preedy (eds.); pp. 337-370). Academic Press.

Horwitz, W. (2010).

Official methods of analysis of AOAC International. Volume I, agricultural chemicals, contaminants, drugs/edited by William Horwitz. Gaithersburg (Maryland): AOAC International, 1997. 


\section{Mai Hussein Abd-Elfatah, Eman E. Abd-Elhady and Amira M. El-Moslemany}

Hui, Y. H. (1992).

Encyclopedia of food science and technology (Issue 664.003 E56e). Wiley,.

Hultcrantz, R., Glaumann, H., Lindberg, G., and H: son Nilsson, L. (1986).

Liver investigation in 149 asymptomatic patients with moderately elevated activities of serum: aminotransferases. Scandinavian Journal of Gastroenterology, 21(1), 109-113.

Jack, K. L., Koopman, W. J., Hulley, D., and Nicolle, M. W. (2016).

A review of azathioprine-associated hepatotoxicity and myelosuppression in myasthenia gravis. Journal of Clinical Neuromuscular Disease, 18(1), 12-20.

Kang, W., Yang, H., Hong, H. J., Han, C. H., and Lee, Y. J. (2012). Anti-oxidant activities of kiwi fruit extract on carbon tetrachloride-induced liver injury in mice. Korean Journal of Veterinary Research, 52(4), 275-280.

Karawya, F. S., and El-Nahas, A. F. (2006).

Theprotective effect of vitamin C on Azathioprine induced seminiferous tubular structural changes and cytogenetic toxicity in albino rats. Cancer Ther, 4, 125-134. 
Egyptian J. of Nutrition Vol. XXXVI No. 1 (2021)

Khudhair, D. (2018).

HISTOPATHOLOGICAL EFFECT OF AZATHIOPRINE ON LIVER , INTESTINE AND. December 2017.

Kind, P. R. N., and King, E. J. (1954).

Estimation of plasma phosphatase by determination of hydrolysed phenol with amino-antipyrine. Journal of Clinical Pathology, 7(4), 322.

Langer, R. M., Jaray, J., Toth, A., Hidvegi, M., Végsö, G., and Perner, F. (2003).

De novo tumors after kidney transplantation: the Budapest experience. Transplantation Proceedings, 35(4), 1396-1398.

Lee, A. U., and Farrell, G. C. (2001).

Mechanism of azathioprine-induced injury to hepatocytes: roles of glutathione depletion and mitochondrial injury. Journal of Hepatology, 35(6), 756-764.

Leontowicz, M., Jesion, I., Leontowicz, H., Park, Y.-S., Namiesnik, J., Rombola, A. D., Weisz, M., and Gorinstein, S. (2013).

Health-promoting effects of ethylene-treated kiwifruit "Hayward" from conventional and organic crops in rats fed an atherogenic diet. Journal of Agricultural and Food Chemistry, 61(15), 3661-3668. 


\section{Mai Hussein Abd-Elfatah, Eman E. Abd-Elhady and Amira M. El-Moslemany}

Leontowicz, H., Leontowicz, M., Latocha, P., Jesion, I., Park, Y.S., Katrich, E., Barasch, D., Nemirovski, A., and Gorinstein, S. (2016).

Bioactivity and nutritional properties of hardy kiwi fruit Actinidia arguta in comparison with Actinidia deliciosa "Hayward" and Actinidia eriantha "Bidan". Food Chemistry, 196 , 281-291.

https://doi.org/10.1016/j.foodchem.2015.08.127

Leontowicz, M., Leontowicz, H., Jesion, I., Bielecki, W., Najman, K., Latocha, P., Park, Y.-S., and Gorinstein, S. (2016).

Actinidia arguta supplementation protects aorta and liver in rats with induced hypercholesterolemia. Nutrition Research, 36(11), 1231-1242.

Lim, Y. J., Oh, C.-S., Park, Y.-D., Eom, S. H., Kim, D.-O., Kim, U.J., and Cho, Y.-S. (2014).

Physiological components of kiwifruits with in vitro antioxidant and acetylcholinesterase inhibitory activities. Food Science and Biotechnology, 23(3), 943-949.

Lou, S., Lai, Y., Huang, J., Ho, C., and Ferng, L. A. (2015). Drying effect on flavonoid composition and antioxidant activity of immature kumquat. FOOD CHEMISTRY, 171, 356-363. 
Egyptian J. of Nutrition Vol. XXXVI No. 1 (2021)

Lou, S., Lai, Y., Hsu, Y., and Ho, C. (2016).

Phenolic content, antioxidant activity and effective compounds of kumquat extracted by different solvents. Food Chemistry, 197, 1-6.

Mandl, J., Szarka, A., and Banhegyi, G. (2009).

Vitamin C: update on physiology and pharmacology. British Journal of Pharmacology, 157(7), 1097-1110.

Manikandaselvi, S., Angumeenal, A. R., Thilagam, S., Poornima, V., and Thinagarbabu, R. (2015).

Immuno stimulant activity of Heterostemma tanjorense (Wight and Arn) on azathioprine induced male albino rats. Journal of Applied Pharmaceutical Science, 5(08), 139-142.

Marcen, R., Pascual, J., Tato, A. M., Teruel, J. L., Villafruela, J. J., Fernandez, M., Tenorio, M., Burgos, F. J., and Ortuno, J. $(2003$

Influence of immunosuppression on the prevalence of cancer after kidney transplantation. Transplantation Proceedings, 35(5), 1714-1716.

Matalon, S. T., Ornoy, A., and Lishner, M. (2004).

Review of the potential effects of three commonly used antineoplastic and immunosuppressive drugs (cyclophosphamide, azathioprine, doxorubicin on the embryo and placenta). Reproductive Toxicology (Elmsford, NY), 18(2), 219-230. 


\section{Mai Hussein Abd-Elfatah, Eman E. Abd-Elhady and Amira M. El-Moslemany}

Matsuo, K., Sasaki, E., Higuchi, S., Takai, S., Tsuneyama, K., Fukami, T., Nakajima, M., and Yokoi, T. (2014).

Involvement of oxidative stress and immune- and inflammation-related factors in azathioprine-induced liver injury. Toxicology Letters, 224(2), 215-224.

Mohamed, D. A., Fouda, K., and Hamed, I. M. (2019).

Protective effect of kumquat fruits and carrot seeds extracts against brain aging in rats. Journal of Herbmed Pharmacology, 8(4), 287-294.

Mohammadi, O., and Kassim, T. A. (2019).

Azathioprine.

Nørgård, B., Pedersen, L., Jacobsen, J., Rasmussen, S. N., and Sørensen, H. T. (2004).

The risk of congenital abnormalities in children fathered by men treated with azathioprine or mercaptopurine before conception. Alimentary Pharmacology and Therapeutics, 19(6), 679-685.

Paoletti, F., and Mocali, A. (1990).

[18] Determination of superoxide dismutase activity by purely chemical system based on NAD (P) $\mathrm{H}$ oOxidation. In Methods in enzymology (Vol. 186, pp. 209-220). Elsevier. 
Egyptian J. of Nutrition Vol. XXXVI No. 1 (2021)

Reeves, P. G., Nielsen, F. H., and Fahey Jr, G. C. (1993).

AIN-93 purified diets for laboratory rodents: final report of the American Institute of Nutrition ad hoc writing committee on the reformulation of the AIN-76A rodent diet. Oxford University Press.

Reitman, S., and Frankel, S. (1957).

A colorimetric method for the determination of serum glutamic oxalacetic and glutamic pyruvic transaminases. American Journal of Clinical Pathology, 28(1), 56-63.

Roy, A. V. (1970).

Rapid method for determining alkaline phosphatase activity in serum with thymolphthalein monophosphate. Clinical Chemistry, 16(5), 431-436.

Satoh, K. (1978).

Estimation of lipid peroxides by thiobarbituric acid reactive substances (TBARS). Clin Chim Acta, 90, 37-43.

Schellekens, P. T., Surachno, S., and Wilmink, J. M. (1982).

A longitudinal study on the effects of azathioprine and high doses of prednisone on the immune system of kidneytransplant recipients. Clinical Immunology and Immunopathology, 24(1), 33-46. 


\section{Mai Hussein Abd-Elfatah, Eman E. Abd-Elhady and Amira M. El-Moslemany}

Shanmugarajan, T. S., Prithwish, N., Somasundaram, I., Arunsundar, M., Niladri, M., Lavande, J. P., and Ravichandiran, V. (2008).

Mitigation of Azathioprine-Induced Oxidative Hepatic Injury by the Flavonoid Quercetin in Wistar Rats. Toxicology Mechanisms and Methods, 18(8), 653-660.

Snedecor, G. W., and Cochran, W. G. (1979).

Design and analysis of sampling. Statistical Methods. GW Snedecor and WG Cochran, Ed. The lowa State University Press, Ames, 504-539.

Tan, S., Li, M., Ding, X., Fan, S., Guo, L., Gu, M., Zhang, Y., Feng, L., Jiang, D., and Li, Y. (2014).

Effects of Fortunella margarita fruit extract on metabolic disorders in high-fat diet-induced obese C57BL/6 mice. PLoS One, 9(4), e93510.

Waffa, S. A., and Farida, A. A. (2012).

Effect of consumption of kiwi fruit on potassium bromate induced oxidative stress in rats. Australian Journal of Basic and Applied Sciences, 6(3), 519-524.

Wu, Y., Shen, C., Yin, J., Yu, J., and Meng, Q. (2006).

Azathioprine hepatotoxicity and the protective effect of liquorice and glycyrrhizic acid. Phytotherapy Research: An International Journal Devoted to Pharmacological and Toxicological Evaluation of Natural Product Derivatives, 20(8), 640-645. 
Egyptian J. of Nutrition Vol. XXXVI No. 1 (2021)

تأثير ثمار الكيوي والكمكوات المجففة على سمية الكبد التي يحدثها الآزاثيوبرين في ذكور الجرذان البيضاء البهاء

مي حسين عبد الفتاح* - إيمان السيد عبد الهادي* ـ أميرة مرسي المسلماني* *قم التغذية و علوم الأطعمة ـ كلية الاقتصاد المنزلي- جامعة الأزهر

الازاثيوبرين (AZA) هو نوع من الأدوية المثبطة للمناعة التي تستخدم عند زراعة

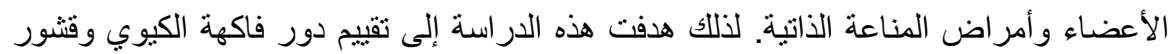

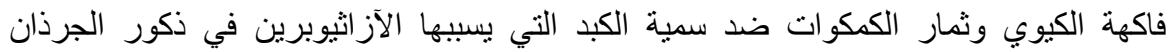

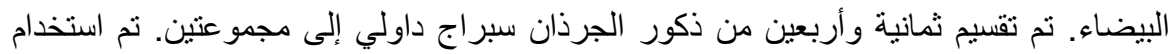

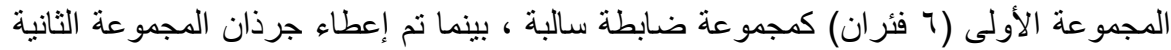

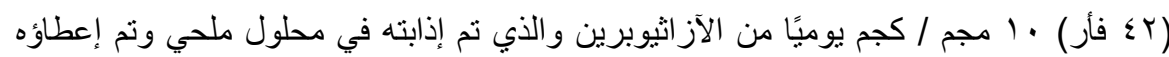

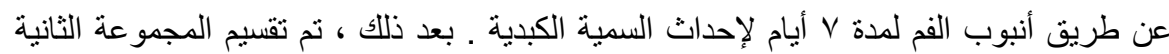

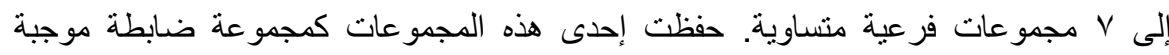

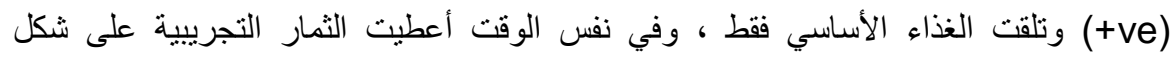

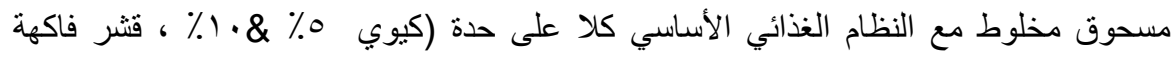

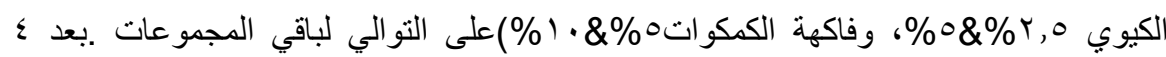

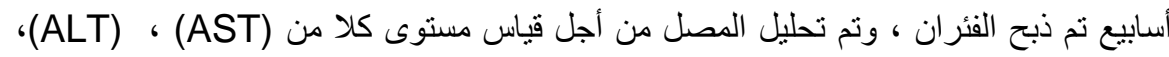

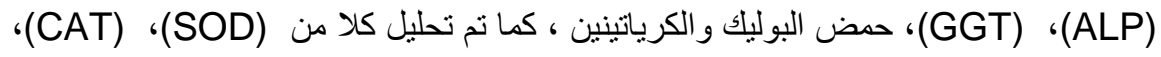
و malondialdehyde (MDA) في أنسجة الكبد وكذلك تم إجراء الفحص النسيجي للكبد

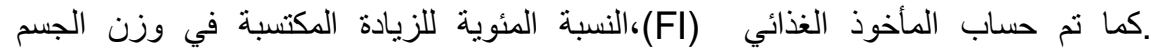

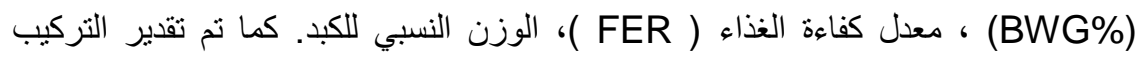

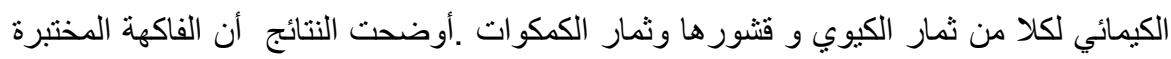

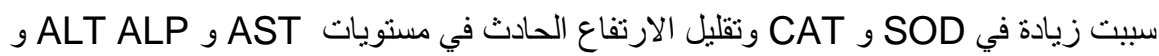

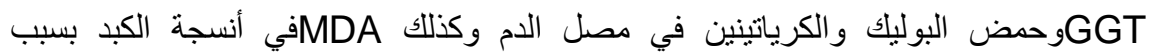
الأزاثيوبرين. أوصت الدراسة بأنه يمكن تقديم الثمار المختبرة كعوامل علاجية مساعدة وفعالة 


\section{Mai Hussein Abd-Elfatah, Eman E. Abd-Elhady and Amira M. El-Moslemany}

للأكسدة والسمية الكبدية بعد إختبار ها علي بعض المنطو عين ، و التي قد تكون بسبب نشاطاتها المضادة 